\title{
PENGARUH KETERAMPILAN TERHADAP PRODUKTIVITAS KERJA KARYAWAN PADA KONVEKSI ISTANA MODE MADIUN
}

\author{
Wiwin Wiranti \\ Mahasiswa Prodi Pendidikan Ekonomi IKIP PGRI Madiun
}

\begin{abstract}
This study aims to determine the Employee Skills in the Konveksi Istana Mode Madiun, to determine Employee Productivity in the Konveksi Istana Mode Madiun, as well as to determine the presence or absence of Vocational Effect on Productivity Among Employees at the Konveksi Istana Mode Madiun. The samples in this study is purposive sampling technique that all employees at the Konveksi Istana Mode Madiun part of convection, amounting to 30 people. Data collection using questionnaires, documentation and interviews. In analyzing the data using statistical methods Product Moment. To test this hypothesis using the $\mathrm{r}$ test, $\mathrm{F}$ test and $\mathrm{t}$ test. The results of the regression analysis of $\mathrm{Y}=\mathrm{a}+$ $\mathrm{bX}$, the result $\mathrm{Y}=11,737+0,757 \mathrm{X}$, to test that rcount $\geq \mathrm{r}$ rtable $(0.784 \geq 0.361)$, or may be rejected $\mathrm{HO}$ means that there is a skills significant relationship with work productivity of employee at the Konveksi Istana Mode Madiun. Furthermore, also obtained results which indicate that the F test of Fcount $\geq F$ table $(44,575 \geq 4.196)$ or $\leq \operatorname{Sig}$ hit $\operatorname{Sig}$ prob $(0,000 \leq 0.05)$. Thus $\mathrm{H} 0$ is rejected, it means there is an overall effect of skills on labor productivity at the Konveksi Istana Mode Madiun. In addition, the t-test results obtained thit $>$ ttab (6.676> $2.048)$ or Sig hit $<\operatorname{Sig}$ prob $(0.000<0.025)$ this situation can be said to be no different from the effect of employee skills on work productivity of employee at the Konveksi Istana Mode Madiun.
\end{abstract}

Keyword: Skills, Work Productivity of Employee

\begin{abstract}
Abstrak: Penelitian ini bertujuan untuk mengetahui Keterampilan Karyawan di Konveksi Istana Modus Madiun, untuk menentukan Produktivitas Karyawan di Konveksi Istana Modus Madiun, serta untuk menentukan ada atau tidak adanya pengaruh pada Produktivitas antara Karyawan di Konveksi Istana Modus Madiun. Sampel dalam penelitian ini adalah teknik purposive sampling bahwa semua karyawan di Konveksi Istana Modus Madiun bagian dari konveksi, sebesar 30 orang. pengumpulan data menggunakan kuesioner, dokumentasi dan wawancara. Dalam menganalisis data menggunakan metode statistik Product Moment. Untuk menguji hipotesis ini menggunakan uji r, uji F dan uji t. Hasil analisis regresi $\mathrm{Y}=\mathrm{a}+\mathrm{bX}$, hasilnya $\mathrm{Y}=11.737+0,757 \mathrm{X}$, untuk menguji bahwa rcount $\geq \mathrm{r}$ rtabel $(0,784 \geq 0,361)$, atau mungkin ditolak H0 berarti bahwa ada keterampilan hubungan yang signifikan dengan pekerjaan produktivitas karyawan di Konveksi Istana Modus Madiun. Selain itu, juga diperoleh hasil yang menunjukkan bahwa uji F dari Fcount $\geq F$ tabel $(44.575 \geq 4,196)$ atau $\leq$ Sighit Sigprob $(0,000 \leq 0,05)$. Dengan demikian H0 ditolak, artinya ada pengaruh secara keseluruhan keterampilan terhadap produktivitas tenaga kerja di Konveksi Istana Modus Madiun. Selain itu, hasil uji t diperoleh thit $>\operatorname{ttab}(6,676>2,048)$ atau Sighit $<$ Sigprob $(0,000<0,025)$ situasi ini dapat dikatakan tidak berbeda dari efek keterampilan karyawan terhadap produktivitas kerja karyawan di Konveksi Istana Mode Madiun.
\end{abstract}

Kata kunci: Keterampilan, Produktivitas Kerja Karyawan 


\section{PENDAHULUAN}

Dalam keadaan perekonomian yang semakin sulit ini banyak terjadi persaingan di berbagai bidang kehidupan, termasuk di dalamya persaingan dalam dunia bisnis. Banyak perusahaan yang saling berlomba untuk mendapatkan pangsa pasar, sehingga hal ini memacu perusahaan untuk berusaha terus maju dalam memperbaiki bisnisnya.

Untuk melakukan perubahan ke arah yang positif, maka dibutuhkan manusiamanusia yang handal sesuai dengan kepentingannya, sehingga manusia harus ditata dalam sebuah manajemen yaitu Manajemen Sumber Daya Manusia (MSDM). Seperti diketahui dalam organisasi terdapat salah satu unsur yaitu : manusia yang merupakan sumber daya penggerak tujuan suatu organisasi dan paling banyak berperan untuk menentukan berhasil tidaknya tujuan perusahaan tersebut.

Intensitas kebutuhan manusia terus mengalami perubahan seiring dengan perkembangan zaman yang terus maju. Berbagai macam sektor dalam bidang ekonomi terus berusaha untuk mencukupi kebutuhan tersebut dengan melakukan berbagai macam pembaharuan. Salah satunya adalah usaha home industry.

Home berarti rumah, tempat tinggal, ataupun kampung halaman. Sedang Industry, dapat diartikan sebagai kerajinan, usaha produk barang dan ataupun perusahaan. Singkatnya, Home Industry (atau biasanya ditulis/dieja dengan "Home Industri") adalah rumah usaha produk barang atau juga perusahaan kecil. Dikatakan sebagai perusahaan kecil karena jenis kegiatan ekonomi ini dipusatkan di rumah. Home Industri juga dapat berarti industri rumah tangga, karena termasuk dalam kategori usaha kecil yang dikelola keluarga.

Pengertian usaha kecil secara jelas tercantum dalam UU No. 20 Tahun 2008, yang menyebutkan bahwa usaha kecil adalah usaha ekonomi produktif yang berdiri sendiri, yang dilakukan oleh orang perorangan atau badan usaha yang bukan merupakan anak perusahaan atau bukan cabang perusahaan yang dimiliki, dikuasai, atau menjadi bagian baik langsung maupun tidak langsung dari usaha menengah atau usaha besar yang memenuhi kriteria Usaha Kecil.

Sumber daya manusia memegang peranan penting dalam proses peningkatan produktivitas, karena alat produksi dan teknlogi pada hakikatnya merupakan hasil pengorbanan. Pada umumya produktivitas yang semakin tinggi merupakan pendayagunaan sumber daya secara efisien. Karena suatu organisasi/perusahaan di dalam proses produksinya harus selalu memperhatikan dan mempertimbangkan bagaimana caranya mencapai produktivitas yang tinggi dengan sumber atau faktor-faktor produksi yang ada.

Setiap organisasi pada dasarnya akan memiliki kebijakan yang berbeda-beda terhadap sumber daya manusia yang dimilikinya guna mencapai produktivitas karyawan. "Dalam pencapaian yang mempengaruhi produktivitas kerja karyawan terdapat banyak faktor yang mempengaruhi produktivitas, salah satunya adalah keterampilan kerja" (Panji Anoraga dan Janti Soegiastuti, 2000:192).

Produktivitas karyawan tidak maksimal jika tenaga kerja yang ada tidak sungguhsungguh dalam menjalankan pekerjaannya. Oleh sebab itu suatu perusahaan memerlukan tenaga kerja yang memiliki keterampilan dalam bekerja pada bidangnya karena keterampilan dapat mendorong suatu produktivitas dan merupakan sarana penting untuk mencapai produktivitas. Dengan demikian setiap tenaga kerja harus meningkatkan keterampilan yang dimiliki agar dapat memberikan yang terbaik untuk industri.

Bagi individu, keterampilan kerja dapat meningkatkan prestasi sehingga memperoleh balas jasa yang sesuai dengan prestasinya. Bagi perusahaan, keterampilan kerja yang dimiliki karyawan berpengaruh pada prestasinya sehingga dapat meningkatkan produktivitas perusahaan. Bagi masyarakat, 
dengan keterampilan kerja individu yang baik dapat meningkatkan kualitas produk yang dihasilkan sehingga masyarakat dapat menikmati kualitas produk tersebut.

Menurut Moeheriono (2010:116) menyatakan "Keterampilan kerja didefinisikan sebagai kemampuan melaksanakan pekerjaan berdasarkan juklak/ juknis atau instruksi dari atasan".

Menurut Basu Swastha dan Ibnu Sukotjo W. (2007:281) menyatakan bahwa "produktivitas adalah sebuah konsep yang menggambarkan hubungan antara hasil (jumlah barang dan jasa yang diproduksi) dengan sumber (jumlah tenaga kerja, modal, tanah, energi, dan sebagainya) yang dipakai untuk menghasilkan hasil tersebut".

Jadi produktivitas merupakan perbandingan atau ukuran kerja antara hasil yang dicapai dengan keseluruhan sumber daya yang digunakan untuk menghasilkan laba.

Menurut Jeff Madura yang diterjemahkan Saroyini W.R. Salib (2001:51) menyebutkan bahwa terdapat beberapa jenis pelatihan yang paling umum diberikan kepada karyawan yaitu (1) Keterampilan Teknis, (2) Keterampilan Pengambilan Keputusan, (3) Keterampilan Pelayanan Pelanggan, (4) Keterampilan Keamanan.

Menurut Pandji Anoraga dan Janti Soegiastuti (2000:192-194), adapun faktorfaktor yang mempengaruhi produktivitas kerja karyawan adalah

1. Motivasi, pimpinan organisasi perlu mengetahui motivasi kerja dari anggota organisasi (karyawan). Dengan mengetahui motivasi itu maka pimpinan dapat mendorong karyawan bekerja lebih baik.

2. Pendidikan, pada umumnya seseorang mempunyai pendidikan yang lebih tinggi akan mempunyai produktivitas kerja yang lebih baik, dengan demikian pendidikan ternyata merupakan syarat yang penting dalam meningkatkan produktivitas kerja karyawan. Tanpa bekal pendidikan mustahil orang akan mudah dalam mempelajari hal-hal yang bersifat baru didalam cara atau suatu sistem kerja.

3. Disiplin kerja adalah sikap kejiwaan seseorang atau kelompok yang senantiasa berkehendak untuk mengikuti atau mematuhi segala peraturan yang telah ditentukan. Disiplin kerja mempunyai hubungan yang sangat erat dengan motivasi, kedisiplinan dengan suatu latihan antara lain dengan bekerja menghargai waktu dan biaya akan memberikan pengaruh yang positif terhadap produktivitas kerja karyawan.

4. Keterampilan banyak pengaruhnya terhadap produktivitas kerja karyawan. Keterampilan karyawan dalam perusahaan dapat ditingkatkan melalui training, kursus-kursus dan lain-lain.

5. Sikap etika kerja, sikap seseorang atau kelompok orang dalam membina hubungan yang serasi, selaras dan seimbang didalam kelompok itu sendiri maupun dengan kelompok lain. Etika dalam hubungan kerja sangat penting karena dengan tercapainya hubungan yang selaras dan serasi serta seimbang antara perilaku dalam proses produksi akan meningkatkan produktivitas kerja.

6. Gizi dan kesehatan, daya tahan tubuh seseorang biasanya dipengaruhi oleh gizi dan makanan yang didapat, dengan itu akan mempengaruhi kesehatan karyawan. Dengan semua itu akan berpengaruh terhadap produktivitas kerja karyawan.

7. Tingkat penghasilan, penghasilan yang cukup berdasarkan prestasi kerja karyawan karena semakin tinggi prestasi karyawan akan makin besar upah yang diterima. Dengan itu maka akan memberikan semangat kerja karyawan akan tercapai.

8. Lingkungan kerja dan iklim kerja, lingkungan kerja dari karyawan disini termasuk hubungan dengan pimpinan, suhu serta dengan lingkungan kerja, penerangan dan sebagainya. Hal ini sangat penting untuk mendapatkan 
perhatian dari perusahaan karena sering karyawan enggan bekerja karena tidak ada kekompakan dalam kelompok kerja atau ruang kerja yang tidak menyenangkan, hal ini akan mengganggu kerja karyawan.

9. Teknologi, dengan adanya kemajuan teknologi meliputi peralatan yang semakin otomatis dan canggih akan dapat mendukung tingkat produksi dan mempermudah manusia dalam melaksanakan pekerjaannya.

10. Sarana produksi faktor-faktor produksi harus memadai dan saling mendukung dalam proses produksi.

11. Jaminan sosial, perhatian dan pelayanan perusahaan kepada setiap karyawan menunjang kesehatan dan keselamatan. Dengan harapan agar karyawan semakin bergairah dan mempunyai semangat untuk bekerja.

12. Manajemen, dengan adanya manajemen yang baik, maka karyawan akan berorganisasi dengan baik, dengan demikian produktivitas kerja karyawan akan tercapai.

13. Kesempatan berprestasi, setiap orang dapat mengembangkan potensi yang ada dalam dirinya dengan diberikan kesempatan berprestasi, maka karyawan akan meningkatkan produktivitas.

\section{METODE PENELITIAN}

Tempat penelitian di Konveksi Istana Mode Madiun, Jalan Dungus Manis No. 1820 Madiun. Desain penelitian yang digunakan dalam penelitian ini penelitian diskriptif. Desain penelitian yang digunakan dalam penelitian ini adalah desain penelitian diskriptif korelasional. Menurut Notoatmojo (dalam Ida dan Wardiyah, 2006:20) penelitian diskriptif korelasional adalah penelitian yang diarahkan untuk menjelaskan hubungan antara dua variabel yaitu variabel bebas dengan variabel terikat.

\section{Variabel Penelitian}

Dalam penelitian ini yang menjadi variabel bebas $(\mathrm{X})$ adalah keterampilan dan dan variabel terikat (Y) adalah produktivitas kerja.

Adapun definisi operasional variabelvariabel tersebut adalah sebagai berikut:

1. Menurut H.A.S. Moenir (2002:117), keterampilan adalah kemampuan melaksanakan tugas/ pekerjaan dengan menggunakan anggota badan dan peralatan kerja yang tersedia.

2. Menurut Ernie Tisnawati Sule dan Kurniawan Saefullah (2008:369), produktivitas adalah ukuran sampai sejauh mana sebuah kegiatan mampu mencapai target kuantitas dan kualitas yang telah ditetapkan.

\section{Teknik Pengumpulan Data}

Teknik pengumpulan data yang digunakan peneliti dalam melakukan penelitian adalah:

\section{Kuesioner atau Angket}

Jumlah soal yang ada dalam angket ini adalah 20 soal yang terbagi dalam 2 variabel yang akan diteliti. 10 soal untuk variabel keterampilan (X) dan 10 soal untuk variabel produktivitas kerja karyawan (Y). Yang menjadi responden dalam teknik pengumpulan data ini adalah 30 karyawan konveksi Istana Mode bagian produksi Kota Madiun.

Instrumen yang digunakan dalam penelitian ini adalah berupa kuesioner. Sistem yang digunakan adalah berupa pemberian skor berdasarkan Skala Likert. Sugiyono (2010:134) menyatakan bahwa "skala likert adalah skala yang digunakan untuk mengukur sikap, pendapat, dan persepsi seseorang atau sekelompok orang tentang fenomena sosial".

\section{Dokumentasi}

Metode dokumentasi digunakan peneliti untuk menyelidiki benda-benda tertulis seperti buku-buku, dokumen, peraturan-peraturan dan sebagainya. Metode ini dipergunakan untuk mendapatkan data 
tentang nama karyawan, jenis kelamin, pendidikan terakhir, profil perusahaan, dan data untuk keterampilan dan produktivitas kerja karyawan yang diperoleh dari konveksi Istana Mode Madiun.

Nana Syaodih Sukmadinata (2007:221) menyatakan bahwa "studi dokumenter merupakan suatu teknik pengumpulan data dengan menghimpun dan menganalisis dokumen-dokumen, baik dokumen tertulis, gambar maupun elektronik".

\section{Wawancara}

Wawancara atau interviu (interview) merupakan salah satu bentuk teknik pengumpulan data yang banyak digunakan dalam penelitian deskriptif kualitatif dan deskriptif kuantitatif (Nana Syaodih Sukmadinata, 2007:216).

Teknik ini merupakan cara untuk memperoleh data dengan menggunakan wawancara langsung pada pemimpin perusahaan atau pemilik perusahaan mengenai keterampilan dan produktivitas kerja karyawan, sehingga dapat diperoleh data yang valid dan dapat dipercaya.

\section{Populasi dan Sampel Penelitian}

Menurut Sugiyono (2012:117), "populasi adalah wilayah generalisasi yang terdiri atas: obyek/subyek yang mempunyai kualitas dan karakteristik tertentu yang ditetapkan oleh peneliti untuk dipelajari dan kemudian ditarik kesimpulannya".

Populasi dalam penelitian ini adalah semua karyawan pada industri konveksi Istana Mode Madiun yang berjumlah 40 karyawan.

Menurut Sugiyono (2012:118), "sampel adalah bagian dari jumlah dan karakteristik yang dimiliki oleh populasi tersebut". Sampel dalam penelitian ini adalah karyawan bagian penjahitan pada Konveksi Istana Mode Madiun.

Adapun yang menjadi sampel dalam penelitian ini yaitu semua karyawan Konveksi Istana Mode Madiun yang berjumlah 30 karyawan pada bagian konveksi.
Teknik pengambilan sampel pada penelitian ini adalah teknik sampling purposive. Menurut Sugiyono (2012:124), "sampling purposive adalah teknik penentuan sampel dengan pertimbangan tertentu."

\section{HASIL PENELITIAN \\ Variabel Keterampilan}

Deskripsi dari variabel keterampilan dengan jumlah data (N) sebanyak 30 memiliki deskripsi data sebagai berikut: (a) Total skor sebesar 1159; (b) Nilai mean sebesar 38,63; (c) Nilai median sebesar 40,00; (d) Nilai modus sebesar 40; (e) Standar deviasi sebesar 5,786; (f) Nilai minimum sebesar 31; (g) Nilai maksimum sebesar 48.

Dari hasil analisis statistik deskriptif keterampilan di atas dapat diketahui dari jumlah karyawan sebanyak 30 orang tangapan terhadap keterampilan karyawan yang berpendapat baik sebanyak 3 orang atau $10,00 \%$, cukup baik sebanyak 15 orang atau $50,00 \%$, kurang baik sebanyak 12 orang atau $40,00 \%$. Hal ini dapat disimpulkan bahwa keterampilan pada konveksi istana mode madiun adalah cukup baik.

\section{Variabel Produktivitas Kerja}

Deskripsi dari variabel produktivitas kerja dengan jumlah data $(\mathrm{N})$ sebanyak 30 memiliki deskripsi data sebagai berikut: (a) Total skor sebesar 1229; (b) Nilai mean sebesar 40,97; (c) Nilai median sebesar 40,00; (d) Nilai modus sebesar 40; (e) Standar deviasi sebesar 5,586; (f) Nilai minimum sebesar 31; (g) Nilai maksimum sebesar 48.

Dari hasil analisis statistik deskriptif produktivitas kerja di atas dapat diketahui dari jumlah karyawan sebanyak 30 orang dalam hal produktivitas kerja karyawan yang mempunyai produktivitas kerja baik sebanyak 5 orang atau $16,70 \%$, cukup baik 16 orang atau 53,33\%, kurang baik sebanyak 9 orang atau $30,00 \%$. Hal ini dapat dapat disimpulkan bahwa produktivitas kerja pada konveksi istana mode madiun adalah cukup baik. 


\section{Persamaan Garis Regresi}

Persamaan garis regresi dinyatakan dengan $\mathrm{Y}=\mathrm{a}+\mathrm{bX}$, diperoleh hasil $\mathrm{Y}=11,737$ $+0,757 \mathrm{X}$, artinya apabila ketrampilan ditingkatkan dengan $1 \%$, akan terjadi kenaikan produktivitas kerja karyawan sebanyak $0,757 \%$, apabila faktor yang lainnya dianggap konstan.

\section{Hasil Uji Korelasi}

Berdasarkan perhitungan hasil uji korelasi dapat diketahui bahwa nilai $\mathrm{r}_{\text {hitung }}$ adalah 0,784 sedangkan nilai $r_{\text {tabel }}$ pada $\mathrm{N}=30$ adalah 0,361 . Hal ini berarti bahwa $r_{\text {hitung }} \geq r_{\text {tabel }}$ $\left(0,784 \geq 0,361\right.$, atau dapat dikatakan $\mathrm{H}_{0}$ ditolak artinya terdapat hubungan yang signifikan ketrampilan dengan produktivitas kerja karyawan pada Konveksi Istana Mode Madiun.

Sedangkan apabila dilihat dari determinasi atau sumbangan variabel $X$ terhadap $Y$ yang dilihat dari nilai $\mathrm{R}^{2}$. Diperoleh nilai $0,784^{2}$ sebesar 0,614 , artinya sumbangan ketrampilan (X) terhadap produktivitas kerja karyawan (Y) sebesar 61,40\%, sedangkan sisanya yang $38,60 \%$ ditentukan oleh faktor lain.

\section{Hasil Uji Fisher}

Berdasarkan perhitungan uji fisher diketahui bahwa nilai $\mathrm{F}_{\text {hitung }}$ sebesar 44,575 sedangkan nilaiF $F_{\text {tabel }}$ dengan $\mathrm{DF}_{1}=1$ dan $\mathrm{DF}_{2}$ atau residu 28 sebesar 4,196. Hal ini berarti bahwa $F_{\text {hitung }} \geq F_{\text {tabel }}(44,575 \geq 4,196)$. Dengan demikian $\mathrm{H}_{0}$ ditolak, artinya ada pengaruh ketrampilan secara keseluruhan terhadap produktivitas kerja karyawan pada Konveksi Istana Mode Madiun.

\section{Hasil Uji t}

Berdasarkan hasil perhitungan diperoleh nilai $t_{\text {hit }}$ sebesar 6,67 , sedangkan $t_{\text {tab }}$ pada $\mathrm{DF}=28$ dan taraf nyata 0,025 sebesar 2,048. Hal ini dapat dikatakan thit $>\operatorname{ttab}(6,67>2,048)$ keadaan ini dapat dikatakan ada beda pengaruh ketrampilan terhadap produktivitas kerja karyawan pada Konveksi Istana Mode Madiun.

\section{Simpulan Hasil Analisis}

Atas dasar hasil pengujian hipotesis dapat diambil simpulan sebagai berikut.

\section{Simpulan Persamaan Garis Regresi}

Persamaan garis regresi dinyatakan dengan $\mathrm{Y}=\mathrm{a}+\mathrm{bX}$, diperoleh hasil $\mathrm{Y}=11,737$ $+0,757 \mathrm{X}$, artinya apabila ketrampilan ditingkatkan dengan $1 \%$, akan terjadi kenaikan produktivitas kerja karyawan sebanyak $0,757 \%$, apabila faktor yang lainnya dianggap konstan.

\section{Simpulan Uji Korelasi}

Dalam uji korelasi dapat diketahui bahwa nilai $r_{\text {hitung }}$ adalah 0,784 sedangkan nilai $\mathrm{r}_{\text {tabel }}$ pada $\mathrm{N}=30$ adalah 0,361 . Hal ini berarti bahwa $r_{\text {hitung }} \geq r_{\text {tabel }}(0,784 \geq 0,361$, atau dapat dikatakan $\mathrm{H}_{0}$ ditolak artinya terdapat hubungan yang signifikan ketrampilan dengan produktivitas kerja karyawan pada Konveksi Istana Mode Madiun.

Sedangkan apabila dilihat dari determinasi atau sumbangan variabel $X$ terhadap $Y$ yang dilihat dari nilai $\mathrm{R}^{2}$. Diperoleh nilai $\mathrm{R}^{2}$ $=(0,784)^{2}$ sebesar 0,614 , artinya sumbangan ketrampilan (X) terhadap produktivitas kerja kerja karyawan (Y) sebesar 61,40\%, sedangkan sisanya yang $38,69 \%$ ditentukan oleh faktor lain.

\section{Simpulan Uji Fisher}

Dari hasil analisis data yang telah dilakukan untuk uji Fisher diperoleh hasil bahwa nilai $F_{\text {hitung }}$ sebesar 44,575 sedangkan nilai $\mathrm{F}_{\text {tabel }}$ dengan $\mathrm{DF}_{1}=1$ dan residu 28 sebesar 4,196. Hal ini berarti bahwa $F_{\text {hitung }} \geq F_{\text {tabel }}$ $(44,575 \geq 4,196)$ Dengan demikian $\mathrm{H}_{0}$ ditolak, artinya ada pengaruh ketrampilan terhadap produktivitas kerja karyawan pada Konveksi Istana Mode Madiun.

\section{Simpulan Ujit}

Nilai $t_{\text {hit }}$ sebesar 6,67 sedangkan $t_{\text {tab }}$ pada $\mathrm{DF}=28$ dan taraf nyata 0,025 sebesar 2,048. 
Hal ini dapat dikatakan thit $>\operatorname{ttab}(6,67>2,048)$ keadaan ini dapat dikatakan ada beda pengaruh ketrampilan terhadap produktivitas kerja karyawan pada Konveksi Istana Mode Madiun.

\section{Pembahasan Hasil Analisis}

Hasil penelitian menunjukkan bahwa ketrampilan mempunyai pengaruh terhadap produktivitas kerja karyawan. Hal ini menunjukkan bahwa dengan kemampuan ketrampilan yang baik dan stabil, dapat mendorong bertambahnya produktivitas kerja karyawan.

Di lain pihak dalam uji hipotesis dengan regresi yang didalamnya memuat persamaan garis regresi, uji korelasi, uji Fisher dan uji t, dalam pembahasannya adalah sebagai berikut:

\section{Persamaan Garis Regresi}

Persamaan garis regresi dinyatakan dengan $\mathrm{Y}=\mathrm{a}+\mathrm{bX}$, diperoleh hasil $\mathrm{Y}=11,737$ $+0,757 \mathrm{X}$, artinya apabila ketrampilan ditingkatkan dengan $1 \%$, akan terjadi kenaikan produktivitas kerja karyawan sebanyak $0,757 \%$, apabila faktor yang lainnya dianggap konstan.

\section{Pembahasan Uji Korelasi}

Analisis dalam uji korelasi diperoleh nilai $r_{\text {hitung }}$ adalah 0,784 sedangkan nilai $r_{\text {tabel }}$ pada $\mathrm{N}=30$ adalah 0,361 . Hal ini berarti bahwa $r_{\text {hitung }} \geq r_{\text {tabel }}(0,784 \geq 0,361$, atau dapat dikatakan $\mathrm{H}_{0}$ ditolak artinya terdapat hubungan yang signifikan keterampilan dengan produktivitaskerja karyawan pada Konveksi Istana Mode Madiun.

Sedangkan apabila dilihat dari determinasi atau sumbangan variabel $\mathrm{X}$ terhadap $\mathrm{Y}$ yang dilihat dari nilai $\mathrm{R}^{2}$. Diperoleh nilai $\mathrm{R}^{2}=(0,784)^{2}$ sebesar 0,614 , artinya sumbangan ketrampilan (X) terhadap produktivitaskerjakerja karyawan (Y) sebesar $61,40 \%$, sedangkan sisanya yang $38,60 \%$ ditentukan oleh faktor lain.

Penolakan $\mathrm{H}_{0}$ tersebut sesuai dengan pendapat Ambar T. Sulistiyani dan Rosidah
(2003:200) menyatakan bahwa ada beberapa faktor yang menentukan besar kecilnya produktivitas antara lain (1) Knowledge, (2) Skiils, (3) Abilities, (4) Attitude, (5) Behaviors.

Keterampilan adalah kemampuan dan penguasaan teknis operasional mengenai bidang tertentu, yang bersifat kekaryaan. Ketrampilan diperoleh melalui proses belajar dan berlatih. Ketrampilan berkaitan dengan kemampuan seseorang untuk melakukan atau menyelesaikan pekerjaan-pekerjaan yang bersifat teknis.

\section{Pembahasan Uji Fisher}

Dalam uji Fisher diperoleh hasil nilai $F_{\text {hitung }}$ sebesar 44,575 sedangkan nilai $F_{\text {tabel }}$ dengan $\mathrm{DF}_{1}=1$ dan residu 28 sebesar 4,196.

Hal ini berarti bahwa $\mathrm{F}_{\text {hitung }} \geq \mathrm{F}_{\text {tabel }}(44,575 \geq$ 4,196). Dengan demikian $\mathrm{H}_{0}$ ditolak, artinya ada pengaruh ketrampilan secara keseluruhan terhadap produktivitas kerja karyawan pada Konveksi Istana Mode Madiun.

Hal ini sesuai dengan apa yang telah dikatakan oleh Pandji Anoraga dan Janti Soegiastuti (2000:193), bahwa faktor-faktor yang mempengaruhi produktivitas kerja salah satunya adalah keterampilan, keterampilan banyak pengaruhnya terhadap produktivitas kerja karyawan, keterampilan karyawan dalam perusahaan dapat ditingkatkan melalui training, kursus, dan lain-lain.

\section{Pembahasan Ujit}

Dalam uji $\mathrm{t}$ diperoleh nilai $\mathrm{t}$ sebesar 6,676 sedangkan $t_{\text {tab }}$ pada $\mathrm{DF}=34$ dan taraf nyata 0,025 sebesar 2,048 . Hal ini dapat dikatakan thit $>$ ttab $(6,676>2,048)$ keadaan ini dapat dikatakan ada beda pengaruh ketrampilan terhadap produktivitaskerja karyawan pada Konveksi Istana Mode Madiun.

Ketrampilan merupakan salah satu tolak ukur dari produktivitas kerja karyawan, hal ini sebagaimana dikatakan oleh Pandji Anoraga dan Janti Soegiastuti (2000:192194), faktor-faktor yang mempengaruhi produktivitas kerja karyawan adalah 
(1) Motivasi, (2) Pendidikan, (3) Disiplin Kerja, (4) Keterampilan, (5) Sikap etika kerja, (6) Gizi dan kesehatan, (7) Tingkat penghasilan, (8) Lingkungan kerja dan iklim kerja, (9) Teknologi, (10) Sarana produksi, (11) Jaminan sosial, (12) Manajemen, (13) Kesempatan berprestasi.

Suatu penelitian akan lebih relevan apabila didukung oleh hasil penelitian orang lain. Hasil penelitian yang dapat dijadikan pendukung adalah hasil penelitian dengan variabel penelitian yang hampir sama tetapi masih dalam pembahasan yang sama.

Elisabeth Novi Ariwardani Perwitasari (2003) dalam penelitiannya yang berjudul "Faktor-faktor Yang Mempengaruhi Kinerja Karyawan Studi Kasus Pada Hotel Dana Solo", dengan hasil penelitian bahwa ada pengaruh yang positif dan signifikan antara pendidikan dan latihan, keterampilan, disiplin, motivasi, upah, jamsostek, lingkungan kerja dan kepemimpinan secara bersama-sama terhadap kinerja karyawan pada Hotel Dana Solo.Dengan uji Regresi Linear Berganda diperoleh hasil besar pengaruh keterampilan terhadap variabel kinerja sebesar 0,288 .

Ria Noviana (2007) dalam penelitiannya yang berjudul "Pengaruh Pelatihan Terhadap Produktivitas Kerja Karyawan Studi Pada CV. Robi Motor Tanjung Tabalong-Kalimantan Selatan", dengan hasil penelitian bahwa terdapat pengaruh yang signifikan dan positif antara pelatihan dan produktivitas kerja karyawan pada CV. Robi Motor Tanjung Tabalong-Kalimantan Selatan. Berdasarkan hasil pengujian hipotesis, variabel pelatihan yang terdiri atas materi pelatihan (X1), pelatih (X2), dan metode pelatihan (X3) secara bersama-sama (simultan) memiliki pengaruh yang signifikan terhadap produktivitas kerja karyawan (Y). Hal ini terbukti kebenaranya, yaitu dari nilai koefisien korelasi (R) sebesar 0,763 , Koefisien Determinasi $\left(\mathrm{R}^{2}\right)$ sebesar 0,582 dan adjusted $R$ Square sebesar 0,555 dengan uji $\mathrm{F}$ hitung sebesar 21,382 > F tabel sebesar 2,84.

Dalam penelitian yang dilakukan di Konveksi Istana Mode Madiun hasil penelitian menunjukkan bahwa keterampilan karyawan berpengaruh terhadap produktivitas kerja karyawan. Hal ini menunjukkan bahwa semua karyawan yang terampil dalam bekerja maka hasil produksi yang dihasilkan akan maksimal.

\section{PENUTUP}

\section{Simpulan}

Keterampilan kerja pada Konveksi Istana Mode Madiun dapat dikatakan cukup baik. Hal tersebut dapat dilihat dari hasil analisis statistik deskriptif dengan jumlah data $(\mathrm{N})$ sebanyak 30 mempunyai deskripsi data sebagai berikut : (a) Total skor sebesar 1159; (b) Nilai mean sebesar 38,63; (c) Nilai median sebesar 40,00; (d) Nilai modus sebesar 40; (e) Standar deviasi sebesar 5,786; (f) Nilai minimum sebesar 31; (g) Nilai maksimum sebesar 48 (lihat Lampiran 6). Dan dari analisis diskriptif tersebut berdasarkan kriteria dari 30 karyawan tanggapan terhadap keterampilan karyawan yang berpendapat baik sebanyak 3 orang atau $10,00 \%$, cukup baik sebanyak 15 orang atau $50,00 \%$, kurang baik sebanyak 12 orang atau $40,00 \%$.

Produktivitas kerja karyawan Konveksi Istana Madiun adalah cukup baik. Hal tersebut dapat dilihat dari hasil analisis statistik diskriptif dengan jumlah data $(\mathrm{N})$ sebanyak 30 memiliki deskripsi data sebagai berikut: (a) Total skor sebesar 1229; (b) Nilai mean sebesar 40,97; (c) Nilai median sebesar 40,00; (d) Nilai modus sebesar 40; (e) Standar deviasi sebesar 5,586; (f) Nilai minimum sebesar 31; (g) Nilai maksimum sebesar 48 (lihat Lampiran 8). Dan dari analisis diskriptif tersebut berdasarkan kriteria dari 30 karyawan dalam hal produktivitas kerja karyawan yang mempunyai produktivitas kerja baik sebanyak 5 orang atau $16,70 \%$, cukup baik 16 orang atau 53,33\%, kurang baik sebanyak 9 orang atau $30,00 \%$. 
Ada pengaruh antara keterampilan terhadap produktivitas kerja karyawan pada Konveksi Istana Mode madiun. Berdasarkan penelitian diperoleh hasil analisis regresi yang dinyatakan dengan $\mathrm{Y}=\mathrm{a}+\mathrm{bX}$, diperoleh hasil $\mathrm{Y}=11,737+0,757 \mathrm{X}$, artinya apabila ketrampilan ditingkatkan dengan $1 \%$, akan terjadi kenaikan produktivitas kerja karyawan sebanyak $0,757 \%$, apabila faktor yang lainnya dianggap konstan.

a. Dari hasil uji korelasi diperoleh nilai korelasi Hal ini berarti bahwa $r_{\text {hitung }} \geq \mathrm{r}_{\text {tabel }}$ $\left(0,784 \geq 0,361\right.$, atau dapat dikatakan $\mathrm{H}_{0}$ ditolak artinya terdapat hubungan yang signifikan keterampilan dengan produktivitas kerja karyawan pada Konveksi Istana Mode Madiun.

b. Apabila dilihat dari determinasi atau sumbangan variabel $\mathrm{X}$ terhadap $\mathrm{Y}$ yang dilihat dari nilai $\mathrm{R}^{2}$. Diperoleh nilai $\mathrm{R}^{2}$ sebesar 0,614 , artinya sumbangan ketrampilan (X) terhadap produktivitas kerja karyawan (Y) sebesar 61,40\%, sedangkan sisanya yang $38,60 \%$ ditentukan oleh faktor lain.

c. Sedangkan dari hasil uji $\mathrm{F}$ diperoleh hasil nilai nilai $F_{\text {hitung }}$ sebesar 44,575 sedangkan nilai $\mathrm{F}_{\text {tabel }}$ dengan DF 1 dan residu 28 sebesar 4,196. Dilain pihak apabila dilihat dari nilai $\mathrm{Sig}_{\text {hit }}$ sebesar 0,000 dan nilai $\operatorname{Sig}_{\text {prob }}$ besarnya 0,05 . Hal ini berarti bahwa $F_{\text {hitung }} \geq F_{\text {tabel }}(44,575 \geq 4,196)$ atau $\operatorname{Sig}_{\text {hit }} \leq \operatorname{Sig}_{\text {prob }}(0,000 \leq 0,05)$. Dengan demikian $\mathrm{H}_{0}$ ditolak, artinya ada pengaruh ketrampilan secara keseluruhan terhadap produktivitas kerja karyawan pada Konveksi Istana Mode Madiun.

d. Selanjutnya dapat dilihat hasil uji $t$ diperoleh hasil nilai t 6,676 dengan sig sebesar 0,000 , sedangkan $t_{\text {tab }}$ pada taraf nyata 0,025 sebesar 2,048 . Hal ini dapat dikatakan thit $>$ ttab $(6,676>2,048)$ atau Sighit $<$ sigprob $(0,000<0,025)$ keadaan ini dapat dikatakan ada beda pengaruh ketrampilan terhadap produktivitas kerja karyawan pada Konveksi Istana Mode Madiun.

\section{Saran}

\section{Bagi Karyawan}

a. Karyawan diharapkan selalu meningkatkan keterampilan yang dimiliki kepada karyawan yang lebih senior.

b. Diharapkan selalu mempertahankan bahkan meningkatkan kualitas barang.

c. Diharapkan selalu bersemangat dalam meningkatkan hasil kerjanya.

\section{Bagi Home Industri}

Diharapkan memberikan pelatihan agar keterampilan yang dimiliki karyawan lebih maksimal, dan barang yang dihasilkan lebih berkualitas.

\section{Bagi Peneliti Mendatang}

Bagi peneliti yang selanjutnya, sebaiknya mengadakan pengembangan penelitian ini dengan menambah atau mencari variabel lain selain keterampilan kerja karena masih banyak faktor yang berpengaruh terhadap produktivitas karyawan, diantaranya pendidikan, sikap etika kerja, teknologi dan lain sebagainya.

\section{DAFTAR PUSTAKA}

Basu Swastha dan Ibnu Sukotjow. 2007. Pengantar Bisnis Modern. Yogyakarta: Liberty Yogyakarta.

Edy Sutrisno. 2011. Manajemen Sumber Daya Manusia. Jakarta: Kencana Prenada Media Group.

Elisabeth Novi Ariwardani Perwitasari. 2003. Faktor-Faktor Yang Mempengaruhi Kinerja Karyawan: Studi Kasus Pada Hotel Dana Solo. Skripsi tidak diterbitkan. Semarang. Program Studi Manajemen Fakultas Ekonomi Unika Soegijapranata.Semarang. (http:// 
eprints.unika.ac.id/.../98.30.3470 elisa beth_novi_ap.pdf, Diunduh 9 Mei 2014).

Ernie Tisnawati Sule dan Kurniawan Saefullah. 2008. Pengantar Manajemen. Jakarta: Kencana Prenada Media Group.

Hamid Darmadi. 2011. Metode Penelitian Pendidikan. Bandung. Alfabeta.

H.A.S. Moenir. 2002. Manajemen Pelayanan Umum Di Indonesia. Jakarta: Bumi Aksara.

Ida Tiur Marisi Simanjuntak dan Wardiyah Daulay. 2006. Hubungan Pengetahuan Keluarga Dengan Tingkat Kecemasan Dalam Menghadapi Anggota Keluarga Yang Mengalami Gangguan Jiwa Di Rumah Sakit Jiwa Propinsi Sumatera Utara, Mean. Jurnal Keperawatan Rufaidah Sumatera Utara, (Online), Vol 2, No 1, (http://repository.usu.ac.id/ bitstream/123456789/21162/1/rufmei2006-02\%20(3)pdf, diunduh 07 Agustus 2014)

I Made Wirartha. 2006. Metodologi Penelitian Sosial Ekonomi. Yogyakarta: CVAndi Offset.

Madura, Jeff. 2001. Pengantar Bisnis. Jakarta: Salemba Empat.

Moeheriono. 2010. Pengukuran Kinerja Berbasis Kompetensi. Bogor: Ghalia Indonesia.

Nana Syaodih Sukmadinata. 2007. Metode Penelitian Pendidikan. Bandung: PT Remaja Rosdakarya Offset.
Oemar Hamalik. 2005. Pengembangan Sumber Daya Manusia, Manajemen Pelatihan Ketenagakerjaan Pendekatan Terpadu. Jakarta: Bumi Aksara.

Pandji Anoraga dan Janti Soegiastuti. 2000. Pengantar Bisnis Modern, Kajian Dasar Manajemen Perusahaan. Jakarta: PT Dunia Pustaka Jaya.

Ria Noviana. 2007. Pengaruh Pelatihan Terhadap Produktivitas Kerja Karyawan, Studi Pada CV. Robi Motor Tanjung Tabalong Kalimantan Selatan. Skripsi tidak diterbitkan. Malang. Program Studi Manajemen Fakultas Ekonomi Universitas Brawijaya. (http://elibrary.ub.ac.id/.../PengaruhPelatihan-Terhadap..., Diunduh 9 Mei 2014).

Sondang P. Siagian. 2003. Manajemen Stratejik. Jakarta: PT Bumi Aksara.

Sri Haryani. 2002. Hubungan Industrial Di Indonesia. Yogyakarta: AMPYKPN.

Sugiyono. 2010. Metode Penelitian Pendidikan, Pendekatan Kuantitatif, Kualitatif, dan R\&D. Bandung: Alfabeta.

Sugiyono. 2012. Metode Penelitian Pendidikan, Pendekatan Kuantitatif, Kualitatif, dan R\&D. Bandung: Alfabeta.

Undang-Undang Republik Indonesia Nomor 20 Tahun 2008 Tentang Usaha Mikro, Kecil, Dan Menengah. (https:// does.google.com/file/d/0BwsNc3hhwp Qn Yukxbepsamzcvvu/edit?pli=1, Diunduh 26 Februari 2014). 